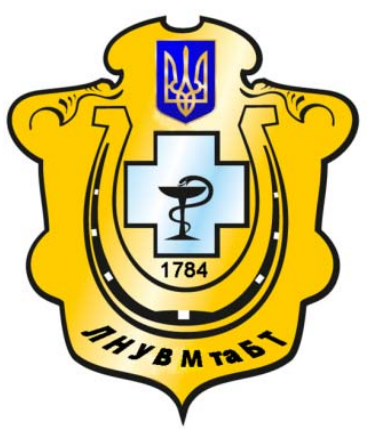

Науковий вісник Львівського національного університету ветеринарної медицини та біотехнологій імені С.3. Гжицького

Scientific Messenger of Lviv National University of Veterinary Medicine and Biotechnologies named after S.Z. Gzhytskyj

doi:10.15421/nvlvet7145

ISSN 2413-5550 print

ISSN 2518-1327 online

$\underline{\text { http://nvlvet.com.ua/ }}$

УДК 639.3:661.47:597.612.128

\title{
Інтенсивність процесів ПОЛ та активність системи антиоксидантного захисту у крові коропів за дії різного рівня вітаміну $\mathbf{E}$ і Селену в раціоні
}

\author{
С.В. Юрчак ${ }^{1}$ О.В. Дерень ${ }^{1}$, О.І. Віщур ${ }^{2}$, Ю.М. Забитівський ${ }^{1}$ \\ Suzanna.8n@gmail.com \\ ${ }^{1}$ Львівська дослідна станція Інституту рибного господарства НААН, \\ вул. Львівська, 11, смт Великий Любінь, Городоцький р-н., Львівська обл., 81555, Украӥна; \\ ${ }^{2}$ Інститут біології тварин НААН, \\ вул. В. Стуса, 38, м. Львів, 79034, Украӥна
}

\begin{abstract}
У статті наведено дані про вплив різного рівня вітаміну Е і Селену в раціоні коропів у переднерестовий період їх вирощування на інтенсивність процесів пероксидного окиснення ліпідів (ПОЛ) та активність системи антиоксидантного захисту (САЗ) в їхньому організмі.

Дослід проведено у трьох експериментальних садках, в які після зимівлі було поміщено чотирирічних статевозрілих самиць і самиів коропа, по шість особин у кожній групі. Самицям і самиям коропів першої дослідної групи (Д1) до основного рачіону $(O P)$ додатково вводили добавки вітаміну Е (фармацевтичний препарат альфа-токоферол ацетат) із розрахунку 25 мг/кг і препарат «Sel-Plex» із розрахунку Селену - 0,3 мг/кг корму. Відповідно друга дослідна група (Д2) отримувала (ОР) i добавки вітаміну Е у кількості 75 мг/кг, і аналогічно, як у Д1 Селену - 0,3 мг/кг корму. Контрольна група риб отримувала (ОР) без добавок вітаміну та мікроелементу. Годівлю проводили впродовж 30 діб з врахуванням фізіологічних потреб риб у кормах. Після нересту у риб дослідних та контрольної груп було взято зразки крові для проведення біохімічних досліджень.

Показано, що згодовування самичям і самиям коропів за місяць до передбачуваного нересту добавок до їхнього раціону вітаміну E і препарату «Sel-Plex» призводило до дозозалежного зниження $(p<0,01-0,001)$ вмісту ТБК-активних продуктів і гідроперекисів ліпідів, проте істотно не впливало на супероксиддисмутазну та глутатіонперокидазну активність крові. Водночас спричиняло тенденцію до підвищення вмісту відновленого глутатіону.

Отже, зменшення продуктів пероксидаиії ліпідів у крові коропів дослідних груп, імовірно було викликано зростанням неферментативної ланки (САЗ), яку пов'язують з жиророзчинними вітамінами.

Ключові слова: плідники коропа, переднерестовий період, вітаміни, мікроелементи, пероксидація, ТБК-активні продукти, супероксиддисмутаза, глутатіонпероксидаза, відновлений глутатіон.
\end{abstract}

\section{Интенсивность процесов ПОЛ и активность системы антиоксидантной защиты в крови карпов при действии различного уровня витамина Е и Селена в рационе}

\author{
С.В. Юрчак ${ }^{1}$, О.В.Дерень ${ }^{1}$, О.И. Вищур ${ }^{2}$ Ю.М. Забытивский ${ }^{1}$ \\ Suzanna.8n@gmail.com \\ ${ }^{1}$ Львовская исследовательская станиця Института рыбного хозяйства НААН, \\ ул. Львовская, 11, пгт Великий Любинь, Городочкий р-н., Львовская обл., 81555, Украина; \\ ${ }^{2}$ Институт биологии животных НААН, \\ ул. В. Стуса, 38, г. Львов, 79034, Украина
}

В статье приведены данные о влиянии различного уровня витамина Е и селена в рационе карпов в преднерестовый

Citation:

Yurchak, S.V., Derenj, O.V., Vishchur, O.I., Zabytivskyi, YU.M. (2016). Intensity of lipid peroxidation and activity of antioxidant systems defence in blood of carps under differenr level of vitamins E and selenium in ration action. Scientific Messenger LNUVMBT named after S.Z. Gzhytskyj, 18, 3(71), 201-204. 
период их выращчивания на интенсивность процессов перекисного окисления липидов (ПОЛ) и активность системьл антиоксидантной защиты (САЗ) в их организме.

Опыт проведен в трех экспериментальных садках, в которые после зимовки было помещено четырехлетних половозрельх самок и самияов карпа, по шесть особей в каждой группе. Самкам и самцам карпов первой опьтной группьл (Д1) к основному рачиону (ОР) дополнительно вводили добавки витамина Е (фармацевтический препарат альфатокоферол ацетат) из расчета 25 мг / кг и препарат «Sel-Plex» из расчета Селена - 0,3 мг/кг корма. Соответственно вторая опитная группа (Д2) получала (ОР) и добавки витамина Е в количестве 75 мг/кг, и также, как в Д1 Селена 0,3 мг/кг корма. Контрольная группа рыб получала (ОР) без добавок витамина и микроэлемента. Кормление проводили в течение 30 суток с учетом физиологических потребностей рыб в кормах. После нереста у рыб опьтных и контрольной групп были взяты образцы крови для проведения биохимических исследований.

Показано, что вскармливание самкам и самиам карпов за месяи до предполагаемого нереста добавок к их раціону витамина E и препарата «Sel-Plex» приводило к дозозависимому снижению (p < 0,01 - 0,001) содержания ТБК-активньх продуктов и гидроперекисей липидов, однако существенно не влияло на супероксиддисмутазную и глутатионпероксидазную активность крови. В то же время вызывало тенденцию к повышению содержания восстановленного глутатиона.

Следовательно, уменьшение продуктов ПОЛ в крови карпов опытных групп, вероятно было вызвано увеличением неферметативного звена (САЗ), которое связывают с жирорастворимыми витаминами.

Ключевые слова: производители карпа, преднерестовый период, витамины, микроэлементы, пероксидация, ТБКактивные продукты, супероксиддисмутаза, глутатионпероксидаза, восстановленный глутатион.

\title{
Intensity of lipid peroxidation and activity of antioxidant systems defence in blood of carps under differenr level of vitamins $\mathbf{E}$ and selenium in ration action
}

\author{
S.V. Yurchak ${ }^{1}$, O.V. Derenj ${ }^{1}$, O.I. Vishchur ${ }^{2}$, YU.M. Zabytivskyi ${ }^{1}$ \\ Suzanna.8n@gmail.com \\ Lviv research station of Institute of fisheries NAAS, \\ Lvivska Str., 11, Velykyi Lyubin, Horodok district, Lviv region 81555, Ukraine; \\ Institute of Animal Biology NAAS, \\ V. Stus Str., 38, Lviv, 79034, Ukraine
}

The article consist data about effect of different levels of vitamin E and selenium in the diet of carps during their growing and also informationabout the influence on processes of lipid peroxidation and activity of antioxidant protection in their body.

The experiment conducted in three experimental ponds. After wintering there were placed four ears mature females and males carp, six individuals in each group. Supplements of vitamin E administered at a rate of $25 \mathrm{mg} / \mathrm{kg}$ and drug «Sel-Plex» the rate of selenium - $0.3 \mathrm{mg} / \mathrm{kg}$ were added to further basic diet(BD) of female and male carp first experimental group (EG1). The second experimental group (EG2) received (BD) and vitamin E supplements in an amount of $75 \mathrm{mg} / \mathrm{kg}$, and just as in EG1 - selenium$0.3 \mathrm{mg} / \mathrm{kg}$ of feed.The control group received fish feed without additives vitamins and minerals. Feeding lasted for 30 days, due to the physiological needs of the fish feed. After spawning in fish of research and control group swere taken blood samples for biochemical research.

The study led to a dose-dependent decrease $(p<0.01-0.001)$ content of TBA-active products and hydroperoxidase of lipids, but did not significantly effect onsuperoxide dismutase and glutathione peroxidase activity of blood So, the reduction of lipid peroxidation products in the carp's blood of experimental groups probably was caused by the growth of non-enzymatic level, which is associated with fat-soluble vitamins.

Key words: spawner carp, prespawning period, vitamins, minerals, peroxidation, TBA-active products, superoxide dismutase, glutathione peroxidase, glutathione.

\section{Вступ}

Відомо, що збільшення споживання поліненасичених жирних кислот рибами призводить до посилення пероксидного окиснення ліпідів в їхньому організмі (Ivanov, 1989; Olsen et al., 1999). Встановлено, що вміст поліненасичених жирних кислот у ліпідах тканин риб більший, ніж у ссавців. При цьому, найбільший вміст їх у фосфоліпідах мікросом. Внаслідок цього риби значно чутливіші до пероксидного окиснення ліпідів і більше залежать від активності антиоксидантної системи в їх організмі. Особливо це актуально у переднерестовий період їх вирощування, оскільки він характеризується посиленням інтенсивності процесів ПОЛ в їхньому організмі (Dudkin, 1990).

В останні роки вітчизняними та зарубіжними дослідниками проведено низку експериментів щодо застосування в годівлі риб вітамінів і мікроелементів 3 метою покращення їх продуктивних характеристик та резистентності організму (Baraboj and Shestakova, 2004; Netyukhaylo and Ishcheykina, 2012; Yanovych and Yanovych, 2014; Vlizlo et al., 2015). 3 метою збільшення антиоксидантного захисту організму в раціон риб вводять жиророзчинний вітамін Е, який відомий своєю антирадикальною дією.

Для посилення дії вітаміну Е часто використовують синергічний йому елемент 3 антиоксидантними властивостями - Селен. Вітамін Е забезпечує включення Селену в склад активного центру глутатіонпероксидази, яка є одним 3 ключових ензимів антиоксидантного захисту.

Мета наших досліджень полягала у з'ясуванні впливу різних кількостей вітаміну Е у комплексі 3 Селеном, у вигляді добавок до раціону коропів у пе- 
реднерестовий період їх вирощування, на інтенсивність процесів ПОЛ та активність САЗ в їхньому організмі.

\section{Матеріал і методи досліджень}

Дослід проведено у Львівській дослідній станції Інституту рибного господарства НААН у трьох експериментальних садках, в які після зимівлі було поміщено чотирирічних статевозрілих самиць і самців коропа, по шість особин у кожній дослідній групі. Після періоду аклімації розпочато переднерестову годівлю плідників збалансованою кормосумішшю, до складу якої входили: рибне борошно, голозерний овес, пшениця, ячмінь, соняшникова олія. Вміст протеїну у кормі становив близько 45\%. Самицям і самцям коропів першої дослідної групи (Д1) до основного раціону додатково вводили добавки вітаміну Е (фармацевтичний препарат альфа-токоферол ацетат) iз розрахунку 25 мг/кг і препарат «Sel-Plex» із розрахунку Селену - 0,3 мг/кг корму. Відповідно друга дослідна група (Д2) отримувала добавки вітаміну Е у кількості 75 мг/кг, і аналогічно, як у Д1 Селену 0,3 мг/кг (препарат «Sel-Plex»). Контрольна група риб отримувала вказану кормосуміш без добавок вітаміну та мікроелементу. Добова потреба корму визначалась за оцінкою наступних показників: маси риб, температури води та вмісту розчиненого кисню, інтенсивності поїдання корму. Годівлю проводили впродовж 30 діб 3 врахуванням фізіологічних потреб риб у кормах при поступовому підвищенні температури, в умовах замкнутого водопостачання. Здійснюючи постійний контроль за температурним, кисневим та хімічним режимами води.

Після нересту у риб дослідних та контрольної груп було взято зразки крові для проведення біохімічних досліджень. У плазмі крові самиць і самців коропа визначали вміст гідроперекисів ліпідів (Myronchyk, 1984) i ТБК-активних продуктів (Korobejnikova, 1989), в еритроцитах крові - активність антиоксидантних ферментів - супероксиддисмутази (Dubinina et al., 1989), глутатіонпероксидази і вмісту відновленого глутатіону (Moin, 1986).

\section{Результати та їх обговорення}

Результати проведених досліджень показали (таблиця), що інтенсивність пероксидних процесів, стан антиоксидантної системи в організмі коропів значною мірою залежать від рівня вітаміну Е і Селену в їхньому раціоні.

Вміст продуктів ПОЛ та активність ензимів системи антиоксидантного захисту у крові коропів

Таблиия $(M \pm m ; n=6)$

\begin{tabular}{|l|c|c|c|}
\hline \multicolumn{2}{|c|}{ Досліджувані показники } & \multicolumn{3}{c|}{ Групи риб } \\
\cline { 2 - 4 } & контроль & дослід 1 & дослід 2 \\
\hline ТБК-активні продукти, /мл нмоль/мл, плазма & $2,53 \pm 0,057$ & $2,47 \pm 0,072$ & $2,26 \pm 0,055^{* *}$ \\
\hline Гідроперекиси ліпідів, од.Е 480/мл, плазма & $1,40 \pm 0,018$ & $1,30 \pm 0,018^{* *}$ & $1,25 \pm 0,011^{* * *}$ \\
\hline Супероксиддисмутаза, ум.од х хв х мг $^{-1}$ білка, еритроцити & $29,5 \pm 0,14$ & $28,7 \pm 0,48$ & $29,9 \pm 0,06$ \\
\hline Глутатіонпероксидаза, нмоль GSH/хв х мг ${ }^{-1}$ білбілка, еритроцити & $19,4 \pm 0,34$ & $20,2 \pm 0,83$ & $20,4 \pm 0,55$ \\
\hline Відновлений глутатіон, мкмоль/мл, еритроцити & $0,32 \pm 0,083$ & $0,39 \pm 0,055$ & $0,38 \pm 0,031$ \\
\hline
\end{tabular}

Так, виявлено значно меншу інтенсивність процесів ПОЛ в організмі коропів, яким упродовж місяця перед нерестом згодовували кормосуміш із добавками вітаміну Е і Селену, порівняно з рибами, які споживали тільки стандартну кормосуміш. Зокрема, у плазмі крові коропів першої і другої дослідних груп вміст гідроперекисів ліпідів був відповідно на 7,1 (p < 0,01) i $10,7 \%(p<0,001)$ менший, ніж у особин контрольної групи. При цьому у крові коропів другої групи, яким згодовували кормосуміш із добавками вітаміну Е у кількості 75 мг/кг і препарату «Sel-Plex» із розрахунку Селену 0,3 мг/кг, вміст ТБК-активних продуктів був на $10,7 \%(\mathrm{p}<0,001)$ менший, ніж у контролі. Ці дані свідчать про інгібуючий і дозозалежний вплив вітаміну Е та Селену на процеси пероксидного окиснення ліпідів у їхньому організмі, особливо на вміст проміжних продуктів пероксидації.

Згодовування коропам дослідних груп упродовж місяця перед нерестом кормосуміші із добавками вітаміну E і Селену істотно не впливало на супероксиддисмутазну та глутатіонперокидазну активність крові, проте спричиняло тенденцію до підвищення вмісту відновленого глутатіону.

Таким чином можна констатувати, що зменшення продуктів пероксидації ліпідів у крові коропів дослід- них груп, імовірно було викликано зростанням неферментативної ланки системи антиоксидантного захисту, яку пов'язують 3 жиророзчинними вітамінами.

\section{Висновки}

Згодовування самицям і самцям коропів у переднерестовий період у складі добавки до кормосуміші вітаміну Е й органічного Селену у формі препарату «Sel-Plex» спричиняло зниження вмісту гідроперекисів ліпідів і ТБК-активних продуктів у плазмі крові й істотно не впливало на супероксиддисмутазну і глутатіонперокидазну активності та вміст відновленого глутатіону.

\section{Бібліографічні посилання}

Ivanov, V.I. (1989). Lipidy biomembran zhivotnyh pri adaptacii $\mathrm{k}$ jekstremal'nym vozdejstvijam [Tekst]:avtoref. dis. ...dokt. biol. nauk : 03.00.04. Tashkent, 36 (in Russian).

Olsen, R.E., Lovaas, E., Lie, Ø. (1999). The influence of temperature, dietary polyunsaturated fatty acids, $\alpha-$ tocopherol and spermineon fatty acid composition and indices of oxidative stress in juvenile Arctic charr, 
Salvelinusalpinus (L.). Biochem. Fish Physiol. 20, 1329.

Dudkin, S.I. (1990). Biologicheskie i sinteticheskie antioksidanty kak nespecificheskie adaptogeny ryb. Vtoroj simp. po jekol. biohimii ryb: Tez.dokl., Rostov Velikij. Jaroslavl', 78-79 (in Russian).

Vlizlo, V.V. Kurtyak B.M., Vudmaska I.V., Vischur A.I., Petruk A.P. (2015). Fat-soluble vitamins in veterinary medicine and animal husbandry, monograms. 2nd ed., Reported. and revised. Lviv, spol (in Ukrainian).

Baraboj, V.A., Shestakova, E.N. (2004). Selen: biologicheskaja rol' i antioksidantnaja aktivnost'. Ukr.biohim. zhurn. 76(1), 23-32 (in Russian).

Netyukhaylo, L.H., Ishcheykina, L.K. (2012). Vitaminy. Svitmedytsyny ta biolohiyi. 4, 191-194 (in Ukrainian).

Yanovych, N.Ye., Yanovych, D.O. (2014). Rol' mikroelementiv u zhyttyediyal'nostistavkovykhryb. Naukovyy visnyk L'vivs'koho natsional'noho universytetu veterynarnoyi medytsyny ta biotekhnolohiy im. Gzhyts'koho. 16, 2(2), 345-372 (in Ukrainian).
Zabytivs'kyy, Yu.M., Yurchak, S.V., Bobelyak, L.Y., Hevkan, I.I. (2014). Vplyv liposomal'noho preparatu z vitaminiv $\mathrm{A}$, $\mathrm{E}$ ta mikroelementiv $\mathrm{Zn}$, Se, I na fiziolohichnyy stan plidnykiv koropa $u$ perednerestovyy period. Rybohospodars'ka nauka Ukrayiny. 4, 86 - 94 (in Ukrainian).

Myronchyk, V.V. (1984). A.s. № 1084681 SSSR, MKY G № 33/48 Sposob opredelenyja gydroperekysej lypydov $\mathrm{v}$ byologycheskyh tkanjah / (SSSR). № 3468369/28-13; zajavl. 08.07.82; opubl. 07.04.84, Bjul. № 13 (in Russian).

Korobejnikova, E.N. (1989). Modifikacija opredelenija produktov perekisnogo okislenija lipidov $\mathrm{v}$ reakcii $\mathrm{s}$ tiobarbiturovoj kislotoj. Lab. delo. 7, 8-9 (in Russian).

Dubinina, E.E. Sal'nikova, L.Ja., Efimova, L.F. (1983). Aktivnost' i izofermentnyj spektr SOD jeritrocitov. Lab. delo. 10, 30-33 (in Russian).

Moin, V.M. (1986). Prostoj i specificheskij metod opredelenija aktivnosti glutationperoksidazy v jeritrocitah. Lab. delo. 12, 724-727 (in Russian).

Стаття надійшла до редакиії 5.09.2016 